\title{
Determinación de la curva tensión-deformación en madera de 'Pinus sylvestris' L. para la simulación numérica de vigas de madera libre de defectos
}

\section{Determination of the stress-strain curve in specimens of Scots pine for numerical simulation of defect free beams}

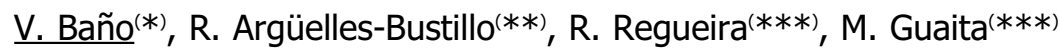

Recepción/Received: 24-XI-10

Aceptación/Accepted: $20-\mathrm{V}-11$

\section{RESUMEN}

El objetivo de este trabajo es el desarrollo de un modelo numérico bidimensional de piezas de madera de Pinus sylvestris L. libre de defectos que prediga su comportamiento frente a solicitaciones externas. Para su desarroIlo, fue necesario realizar ensayos experimentales sobre probetas de pequeño tamaño con el fin de obtener los datos de las propiedades mecánicas para el Pinus sylvestris $\mathrm{L}$. de procedencia española. A partir de los datos experimentales obtenidos, se desarrolla un programa de elementos finitos que considera la ortotropía de la madera, la no linealidad de la rama compresión-acortamiento y los distintos módulos de elasticidad a tracción y a compresión para vigas libres de defectos. El programa simula el ensayo experimental de flexión en cuatro puntos según la Norma UNE-EN 408 y aborda la determinación de las tensiones y deformaciones de las vigas de madera en las tres fases de comportamiento: elástica, elastoplástica y plástica.

Palabras clave: madera estructural, simulación numérica, MEF, Pinus sylvestris L.

\section{SUMMARY}

The objective of this paper is to develop a twodimensional numerical model to simulate the response of Scots pine (Pinus sylvestris L.) defect free timber members in order to predict the behaviour of these members when subjected to external forces. For this purpose, data of the mechanical properties of Scots pine were obtained by performing experimental tests on specimens. We determined the stresses and deformations of timber beams in the elastic-plastic and plastic phases. In addition, we developed a finite element software that considered the orthotropic nature of timber, the non-linearity of the compression-reduction branch and the differing moduli of elasticity in tension and compression for Scots pine beams free from defects. The software developed simulates an experimental four point bending test according to UNE-EN 408 Standard.

Keywords: timber construction, numerical simulation, FEM, Pinus sylvestris $L$.

(*) CETEMAS, Centro Tecnológico Forestal y de la Madera, Grado (Asturias, España).

(**) Universidad Politécnica de Madrid, Madrid (España).

(***) Universidade de Santiago de Compostela, Lugo (España). 


\section{INTRODUCCIÓN}

La madera es un material anisótropo, con distintas propiedades según las tres direcciones principales: axial, radial y tangencial; y donde el módulo de elasticidad a tracción difiere del de compresión.

En una viga sometida a flexión simple, la curva tensióndeformación en compresión es solo parcialmente elástica, ya que a partir de cierta deformación $\left(\varepsilon_{c, y}\right)$, variable con la especie, se entra en una zona de deformaciones elastoplásticas, que finaliza en un tramo recto bajo tensión constante $\left(f_{c, 0, u}\right)$, asociada a unas deformaciones que varían entre $\left(\varepsilon_{c, 0, p}\right)$ y $\left(\varepsilon_{c, 0, u}\right)$. La curva tensión-deformación en tracción es elástica hasta la rotura, adoptando la pendiente un ángulo de inclinación $(\beta)$, mayor que el de compresión en tramo elástico $(\alpha)$, Figura 1 .

\section{INTRODUCTION}

Wood is an anisotropic material, with different properties in the three directions of the grain: axial, radial and tangential. In wood, the tensile modulus of elasticity differs from the compressive modulus of elasticity.

In a bending beam, the compressive stress-strain curve is only partially elastic because, above certain strain values $\left(\varepsilon_{c, y}\right)$ which vary with species, the material enters an area of elastic-plastic deformations that ends in a straight segment under constant stress $\left(f_{c, 0, u}\right)$, associated with strain values in the range $\left(\varepsilon_{c, 0, p}\right)$ and $\left(\varepsilon_{c, 0, r}\right)$, Figure 1 .

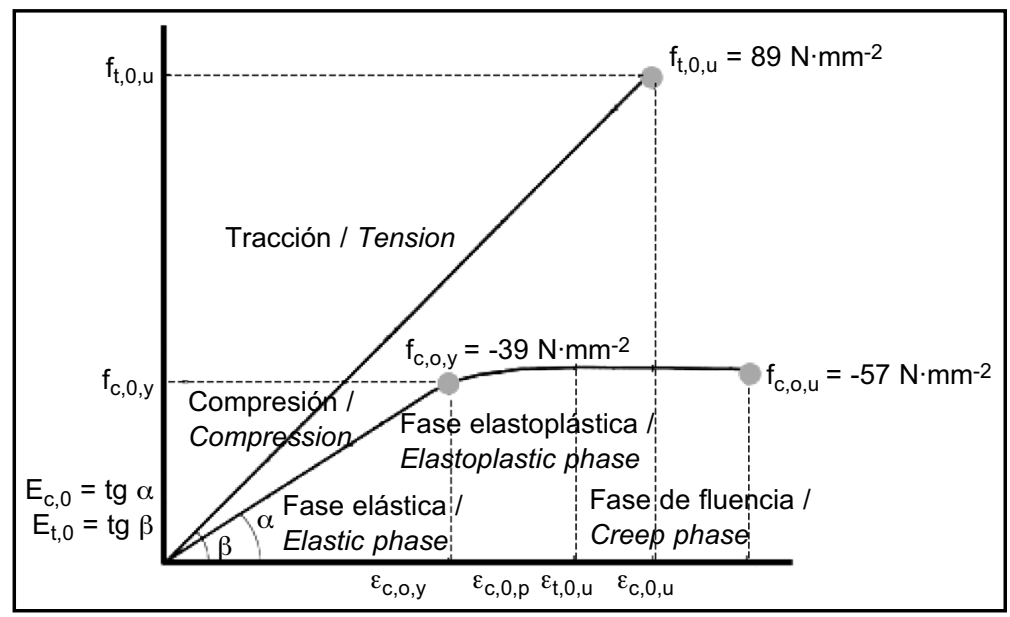

Figura 1. Valores de límite elástico y resistencia última para madera de Pinus sylvestris $L$. Figure 1. Values of ultimate strength and yield stress for Scots pine timber.

Si se admite la hipótesis de tensión plana de la sección, en los primeros estados de carga la ley de tensiones seguirá una distribución formada por dos rectas con diferente pendiente. Como consecuencia de este comportamiento, la fibra neutra desciende, alejándose del comportamiento clásico de la resistencia de materiales para sólidos isótropos, con la fibra neutra en el eje de la pieza para flexión simple (Figura 2).

A efectos de valorar las deformaciones para esta solicitación se considera un módulo de elasticidad aparente en la fase elástica que se obtiene a partir de los valores de módulo de elasticidad de tracción y de compresión. Admitiendo que las deformaciones son lineales, y que existe equilibrio entre los volúmenes de tracción y compresión, el módulo de elasticidad virtual $\mathrm{E}_{\mathrm{m}}$ se deduce según la ecuación [1].
Let us assume that the section is in plane stress state. At low load levels, the stresses are distributed along two straight lines with different slopes. As a result, the neutral axis shifts down, a behaviour that deviates from the classic behaviour of isotropic solids according to the strength of materials theory, in which the neutral axis is located at the axis of the member under simple bending (Figure 2).

In the first elastic phase, both the tensile and compressive moduli of longitudinal elasticity in bending can be considered for the selection of an apparent modulus of elasticity to assess bending deformations. Assuming linear deformations, the equilibrium between the volume of tension and the volume of compression suggests that $E_{m}$ must be considered as the modulus of elasticity, equation [1].

$$
E_{m}=\frac{4 \cdot E_{t, 0} \cdot E_{c, 0}}{\left(\sqrt{E_{t, 0}}+\sqrt{E_{c, o}}\right)^{2}}
$$




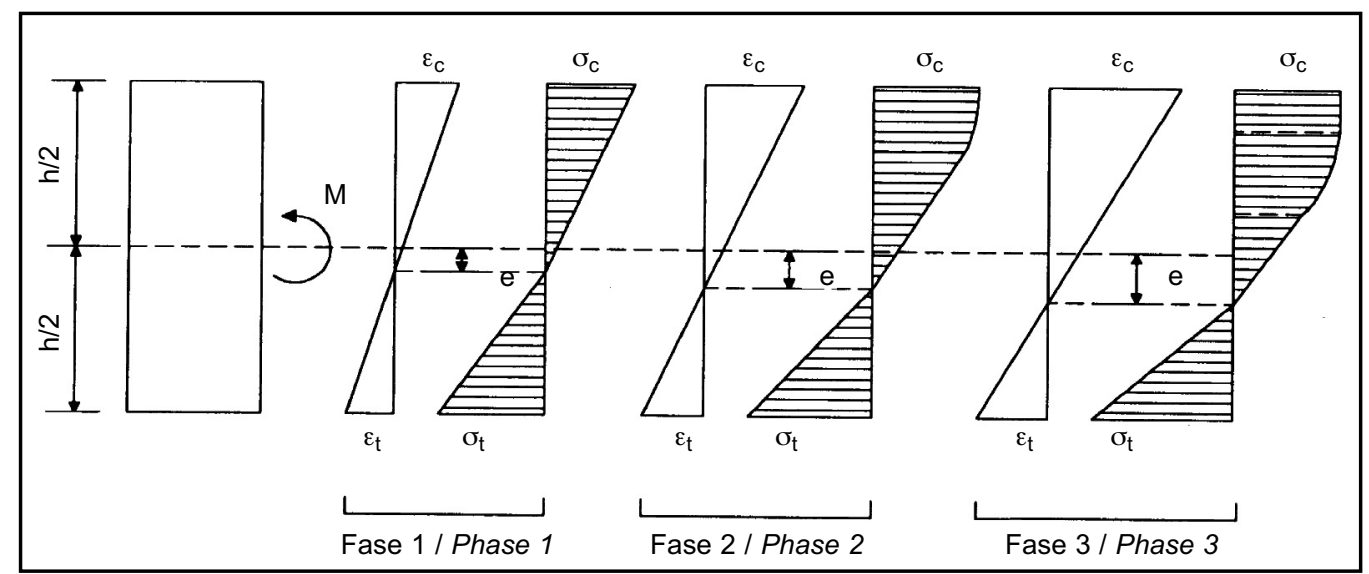

Figura 2. Esquema del descenso de la fibra neutra en una viga sometida a flexión simple (1). Figure 2. Diagram of the downward shift of the neutral axis in a beam under simple bending (1).

donde $E_{c, 0}$ es el módulo de elasticidad en compresión paralela a la fibra y $\mathrm{E}_{\mathrm{t}, 0}$ es el módulo de elasticidad en tracción paralela a la fibra, ambos en fase elástica.

En la fase elastoplástica de comportamiento del material, el análisis es difícilmente abordable en base a la resistencia de materiales, ya que el módulo de elasticidad en cada sección no es constante, variando en función del momento flector. De aquí surge la necesidad de recurrir a un procedimiento de cálculo específico basado en el método de los elementos finitos (1).

\subsection{Antecedentes}

Las publicaciones existentes de caracterización estructural según normativa vigente se centran en la determinación de los valores necesarios para la asignación de una clase resistente, dentro del comportamiento lineal y elástico. En lo referente a la especie Pinus sylvestris L., Hermoso et al., 2003 (2), realizaron la caracterización mecánica de diversas procedencias españolas de acuerdo a la Norma UNE-EN 408 (3), con el fin de establecer los valores correspondientes a la clase resistente de acuerdo con lo establecido en las normas UNE-EN 384 (4) y UNE-EN 338 (5), para un total de 3.085 piezas y varias dimensiones de pequeña escuadría (espesor $\leq 70 \mathrm{~mm}$ ). Fernández Golfín et al., 2003 (6), realizaron estudios con el objetivo de establecer la relación entre las propiedades que determinan la clase resistente de la madera del pino silvestre y pino laricio.

Para conocer los mecanismos de fallo que conducen a la rotura, es necesario un análisis mediante simulación numérica con el fin de determinar los valores de las propiedades mecánicas de naturaleza elastoplástica.

La combinación de técnicas de elementos finitos (MEF) y la teoría de la resistencia de materiales han resultado ser where $E_{c, 0}$ is the modulus of elasticity in compression parallel to the grain and $E_{t, 0}$ is the modulus of elasticity in tension parallel to the grain, both in the elastic phase.

In the elastoplastic phase, the analysis can hardly be approached using the strength of materials theory because the modulus of elasticity is not constant at every section and varies based on bending moment. Therefore it is necessary to use a specific finite element calculation method (1).

\subsection{Background}

Structural characterization studies based on current standards focus on the determination of the values required to allocate timber to a strength class assuming a linear elastic behaviour. For Scots pine, Hermoso et al., 2003 (2), carried out the mechanical characterization of Scots pine timber from different Spanish provenances in accordance with UNE-EN 408 (3), and determined the mechanical values for the corresponding strength class according to UNE-EN 384 (4) and UNE-EN 338 (5) standards. A total of 3085 boards of various sizes (thickness $\leq 70 \mathrm{~mm}$ ) were tested. Fernández Golfín et al., 2003 (6), stablished the relationships between grade determining properties of Spanish Scots and Laricio pine structural timber.

To determine failure modes beyond the modulus of fracture a numerical simulation analysis is required, such that the values of the elastic-plastic mechanical properties can be determined.

Combining FEM techniques and strength theory to predict the ultimate capacity has proven to be a valuable 
una herramienta valiosa para la predicción de la capacidad última de resistencia en madera aserrada. Varios autores, como Gupta et al., 2002 (7), Dubois et al., 2002 (8), Landis et al., 2003 (9) y 2007(10), y Coureau et al., 2006 (11), han usado este método para simular el comportamiento de madera aserrada libre de defectos como un material elástico. Otros autores, como Ormarsson et al., 2006 (12), Daudeville et al., 1999 (13), Williams et al., 2000 (14), y Chassagne et al., 2005 (15), han simulado la madera aserrada libre de defectos como un material elastoplástico no lineal. Con este mismo comportamiento no lineal, Villar et al., 2007 (16) y 2008 (17), aplicaron la simulación numérica a las uniones tradicionales madera-madera, incorporando el rozamiento entre superficies de contacto.

También en el ámbito de las uniones de madera, Köck et al., 2010 (18), aplicaron el método de los elementos finitos para predecir el comportamiento carga-deformación de uniones, suponiendo un comportamiento de la madera lineal en tensión-deformación, definiendo el comportamiento elastoplástico como una recta. Con este mismo comportamiento Jasieńko et al., 2010 (19), usaron un modelo plástico idealmente elástico para analizar el comportamiento estático de vigas de madera reforzadas con polímeros de fibra de carbono (CFRP). Ambos consideraron el tramo elastoplástico como un tramo recto en la curva tensión-deformación, con una pendiente diferente al tramo elástico.

\subsection{Objetivos}

El principal objetivo de este trabajo es la creación de un modelo basado en el método de los elementos finitos usando el software comercial ANSYS que pueda estimar las cargas de rotura en vigas de madera limpia de Pinus sylvestris L. procedente de Valsaín, España.

Con el fin de realizar la correcta simulación de piezas de madera según métodos numéricos, se plantea un primer objetivo parcial de obtención del diagrama tensión-deformación de la madera de Pinus sylvestris L. Por lo tanto, para poder obtener la curva de comportamiento elastoplástico a compresión es necesario realizar ensayos experimentales en probetas de madera libre de defectos.

El segundo objetivo parcial se centra en la simulación numérica mediante MEF del ensayo a flexión de cuatro puntos, UNE-EN 408 (3), con el fin de obtener la distribución de tensiones a lo largo del canto de la viga, tanto en el comportamiento elástico del material como en el comportamiento elastoplástico, deduciendo el descenso de la fibra neutra, a medida que se plastifica la parte comprimida de la viga. El tercer objetivo parcial es la determinación de la influencia que tienen los módulos de elasticidad en la deformación de las vigas. tool for solid sawn timber. Several authors, such as Gupta et al., 2002 (7), Dubois et al., 2002 (8), Landis et al., 2003 (9) and 2007 (10), and Coureau et al., 2006 (11), have used this method to simulate the behaviour of clear sawn timber as a linear elastic material. Other authors, such as Ormarsson et al., 2006 (12), Daudeville et al., 1999 (13), Williams et al., 2000 (14), and Chassagne et al., 2005 (15), have simulated clear sawn timber as a non-linear elastic-plastic material. Assuming a non-linear behaviour of the material, Villar et al., 2007 (16) and 2008 (17), applied numerical simulation to timber-to-timber traditional joints and incorporated the effect of friction between contacting surfaces.

Köck et al., 2010 (18), used the finite element method to predict the load-displacement behaviour of halved joints, assuming a linearised stress-strain behaviour of timber and defining the elastic-plastic behaviour as a straight line. Jasieńko et al., 2010 (19), used an elastic-ideally plastic model to analyze the static behaviour of wooden beam cross-sections reinforced with carbon fibre reinforced polymers (CFRP). Both considered the elastoplastic phase as a straight on the stress-strain diagram, with a different slope that elastic phase.

\subsection{Objectives}

The main objective of this paper is to create a FEMbased model using the ANSYS commercial software that can be used as an estimator of the modulus of fracture in clear wood beams of Scots pine from Valsaín, Spain.

In order to correctly simulate timber members using numerical methods, our first objective is to obtain the stress-strain curve for Scots pine timber. To obtain the curve for elastic-plastic behaviour in compression, it is necessary to perform experimental tests on wood specimens free from defects.

Our second objective is to perform a finite element simulation of a four point bending test (UNE-EN 408) (3) in order to obtain the stress distribution along the beam depth, assuming both an elastic behaviour and an elastic-plastic behaviour of the material and capturing the downward shift of the neutral axis as the compressed part of the beam becomes more plastic. Our third objective is to determine the effects of the moduli of elasticity on beam deformation. 


\section{MATERIAL Y MÉTODOS}

\subsection{Análisis experimental}

Con el fin de determinar las propiedades mecánicas de la madera de pino silvestre de procedencia española, se realizaron diversos ensayos sobre probetas de madera libre de defectos de esta especie.

Los ensayos de compresión paralela a la fibra se realizaron sobre 34 probetas de tamaño $20 \times 20 \times 60 \mathrm{~mm}$ en un banco de ensayos universal Suzpecar, con una capacidad resistente de $50 \mathrm{kN}$ y una sensibilidad de $100 \mathrm{~N}$, según UNE 56535. Aplicando la carga de compresión de manera concéntrica sobre la probeta, se obtuvieron las deformaciones asociadas a la misma en el tramo elástico de comportamiento de la madera, medidas con una galga extensométrica colocada en la dirección longitudinal. A partir de la deformación de la probeta en la fase elástica, y conociendo la carga aplicada, se obtuvo el módulo de elasticidad a compresión paralela a la fibra $\left(E_{c, 0}\right)$, según la ecuación [2].

\section{MATERIAL AND METHODS}

\subsection{Experimental test}

To determine the mechanical properties of Scots pine timber of Spanish provenance, a number of tests were carried out on clear wood specimens.

Compression tests parallel to the grain were carried out on 34 specimens of size $20 \times 20 \times 60 \mathrm{~mm}$ in size using the Suzpecar universal testing machine, with $50 \mathrm{kN}$ strength capacity and a sensitivity of $100 \mathrm{~N}$, according to UNE 56535. Following the concentric application of the compressive load, the deformations associated with the load applied to the specimen in the elastic phase were measured in the longitudinal direction using an extensometer. The modulus of elasticity in compression parallel to the grain $\left(E_{c, 0}\right)$ was determined based on the deformation of the specimen in the elastic phase and on the load applied, using equation [2].

$$
E_{c, 0}=\sigma_{c, 0} / \varepsilon_{c, 0}
$$

donde $\mathrm{E}_{\mathrm{c}, 0}$ es el módulo de elasticidad en compresión paralela a la fibra, $\sigma_{c, 0}$ es la tensión aplicada sobre la probeta sometida a compresión $\left(\mathrm{N} / \mathrm{mm}^{2}\right)$ y $\varepsilon_{\mathrm{c}, 0}$ es la deformación obtenida por la aplicación de la fuerza.

Una vez obtenidos los valores de deformación en el tramo elástico, se prolongó el ensayo a compresión paralela a la fibra hasta alcanzar la rotura. La resistencia a compresión paralela a la fibra $\left(\mathrm{f}_{\mathrm{c}, 0, \mathrm{u}}\right)$ se obtuvo mediante la aplicación de la ecuación [3]. where $E_{c, 0}$ is the modulus of elasticity in compression parallel to the grain, $\sigma_{c, 0}$ is the stress applied to the specimen under compression $\left(\mathrm{N} / \mathrm{mm}^{2}\right)$ and $\varepsilon_{c, 0}$ is the deformation under applied load.

After the values of deformation in the elastic phase were obtained, the compression test parallel to the grain was continued until failure. The compressive strength parallel to the grain $\left(f_{c, 0, u}\right)$ was obtained using equation [3].

$$
f_{c, 0, u}=F_{\max } / A
$$

donde $\mathrm{f}_{\mathrm{c}, 0, \mathrm{u}}$ es la resistencia a compresión paralela a la fibra $\left(\mathrm{N} / \mathrm{mm}^{2}\right), \mathrm{F}_{\text {máx }}$ es la carga máxima aplicada en el momento de la rotura $(\mathrm{N})$ y $\mathrm{A}$ es el área de la sección transversal $\left(\mathrm{mm}^{2}\right)$.

Mediante la realización de este ensayo se obtuvieron los parámetros que definen el diagrama tensión-deformación a compresión paralela a la fibra de la madera de Pinus sylvestris L. (Figura 1), compuesto por el módulo de elasticidad en el tramo elástico $\left(E_{c, 0}\right)$, los módulos de elasticidad en la fase elastoplástica, el límite elástico a compresión $\left(\mathrm{f}_{\mathrm{c}, 0, \mathrm{y}}\right)$ y la tensión de rotura a compresión $\left(\mathrm{f}_{\mathrm{c}, 0, \mathrm{u}}\right)$. where $f_{c, 0, u}$ is the compressive strength parallel to the grain $\left(\mathrm{N} / \mathrm{mm}^{2}\right), F_{\text {máx }}$ is the maximum load at failure $(\mathrm{N})$ and $A$ is the cross-sectional area $\left(\mathrm{mm}^{2}\right)$.

The parameters that defined the strain-stress curve for Scots pine timber in compression parallel to the grain were obtained from the compression test parallel to the grain (Figure 1). The following parameters were obtained: modulus of elasticity in the elastic phase $\left(E_{c, 0}\right)$, moduli of elasticity in the elastic-plastic phase, yield stress in compression $\left(f_{c, 0, y}\right)$ and ultimate compressive strength $\left(f_{c, 0, u}\right)$. 
Se realizaron además ensayos de tracción paralela a la fibra sobre un total de 82 probetas de dos tamaños diferentes: a) $30 \times 10 \mathrm{~mm}$ de sección y longitud total de $250 \mathrm{~mm}$, con una longitud libre de $150 \mathrm{~mm}$, y b) 30 x $10 \mathrm{~mm}$ de sección y longitud total de $300 \mathrm{~mm}$, con una longitud libre de $150 \mathrm{~mm}$.

Las probetas se sujetaron por medio de mordazas que permitieron la aplicación de una carga de tracción sin provocar flexión hasta la rotura de la probeta. La deformación se midió mediante la colocación de galgas extensométricas colocadas en el tramo central de las probetas.

La utilización de dos tamaños de probeta en el ensayo se debió a la dificultad de la sujeción de las probetas de menor longitud, por lo que se amplió el ensayo a las probetas más largas. Los ensayos se realizaron con dos máquinas diferentes, la máquina Suzpecar descrita anteriormente y la máquina Mohr, capaz de proporcionar una fuerza de tracción de $40 \mathrm{kN}$. Se consideraron únicamente los resultados de los ensayos de las probetas de mayor tamaño (longitud total $=300 \mathrm{~mm}$ ) y de las probetas de longitud total igual a $250 \mathrm{~mm}$ que resultaron válidos durante la realización del ensayo.

A partir de la deformación de la probeta, y conocida la carga aplicada, se obtuvo el módulo de elasticidad a tracción paralela a la fibra $\left(E_{t, 0}\right)$, a partir de la ecuación [4].
In addition, tension tests parallel to the grain were carried out on 82 specimens of two sizes: a) $30 \times 10 \mathrm{~mm}$ in crosssection and $250 \mathrm{~mm}$ in total length, with a free length of $150 \mathrm{~mm}$ and b) $30 \times 10 \mathrm{~mm}$ in cross-section and $300 \mathrm{~mm}$ in total length, with a free length of $150 \mathrm{~mm}$.

The specimens were tested using gripping devices, which permitted the application of a tensile load without causing bending. Deformation was measured using extensometers located at the centre of the section.

Specimens of two different lengths were used because the $250 \mathrm{~mm}$ long specimens were difficult to hold; therefore, specimens of longer lengths $(300 \mathrm{~mm})$ were necessary to conduct the test. Tension tests were performed using two different machines, the Suzpecar universal testing machine and the Mohr tensile test machine, which is able to provide a tensile force of up to $40 \mathrm{kN}$. The results considered in this study include the measurements done on the $300 \mathrm{~mm}$ long specimens and the $250 \mathrm{~mm}$ long specimens which could be held during the test.

The modulus of elasticity in tension parallel to the grain $\left(E_{t, 0}\right)$ was determined based on the deformation of the specimen and on the applied load, using equation [4].

$$
E_{t, 0}=\sigma_{t, 0} / \varepsilon_{t, 0}
$$

donde $\mathrm{E}_{\mathrm{t}, 0}$ es el módulo de elasticidad en tracción paralela a la fibra, $\sigma_{t, 0}$ es la tensión aplicada sobre la probeta sometida a tracción $\left(\mathrm{N} / \mathrm{mm}^{2}\right)$ y $\varepsilon_{\mathrm{t}, 0}$ es la deformación obtenida por la aplicación de la fuerza aplicada.

Una vez obtenidos los valores de deformación a tracción se continuó el ensayo hasta provocar la rotura de las probetas, sin provocar flexión, con el fin de medir la fuerza aplicada. La resistencia a tracción paralela a la fibra $\left(f_{t, 0, u}\right)$ se obtuvo a partir de la ecuación [5]. where $E_{t, 0}$ is the modulus of elasticity in tension parallel to the grain; $\sigma_{t, 0}$ is the stress applied to the test piece under tension $\left(\mathrm{N} / \mathrm{mm}^{2}\right)$ and $\varepsilon_{t, 0}$ is the deformation under applied load.

After the values of tensile deformation were obtained, the tension test was continued without inducing bending in order to measure the applied load. The tensile strength parallel to the grain $\left(f_{t, 0, u}\right)$ was obtained using equation [5].

$$
f_{t, 0, u}=F_{\text {máx }} / A
$$

donde $\mathrm{f}_{\mathrm{t}, 0, \mathrm{u}}$ es la resistencia a tracción paralela a la fibra $\left(\mathrm{N} / \mathrm{mm}^{2}\right), \mathrm{F}_{\text {máx }}$ es la carga máxima aplicada en el momento de la rotura $(\mathrm{N})$ y $\mathrm{A}$ es el área de la sección transversal $\left(\mathrm{mm}^{2}\right)$.

A partir de un ensayo de compresión oblicua, utilizando 32 probetas cúbicas de dimensiones $60 \times 60 \times 60 \mathrm{~mm}$ con la fibra orientada un ángulo de $45^{\circ}$ respecto a la dirección de las tensiones de compresión en un plano paralelo a una de las caras del cubo, se determinó el valor del módulo de elasticidad transversal (Figura 3). where $f_{t, 0, u}$ is tensile strength parallel to the grain $\left(\mathrm{N} / \mathrm{mm}^{2}\right), F_{\text {máx }}$ is the maximum load at failure $(N)$ and $A$ is the cross-sectional area $\left(\mathrm{mm}^{2}\right)$.

The value of shear modulus was obtained from an oblique compression test using 32 cubic specimens 60 $\mathrm{mm}$ size with the grain at $45^{\circ}$ to the compression stress direction in a plane parallel to a side of cube (Figure 3). 
Las mediciones de deformación se realizaron con galgas extensométricas triaxiales. El valor del módulo de elasticidad transversal, G, se obtuvo a partir de la ecuación [6] (21).
Deformation measurements were carried out using triaxial strain gauges. The value of the shear modulus, $G$, was obtained using of equation [6] (21).

$$
G=\frac{\sigma_{y^{\prime}}}{2 \cdot\left(\varepsilon_{x^{\prime}}-\varepsilon_{y^{\prime}}\right)}
$$

donde $\mathrm{G}$ es el módulo de elasticidad transversal, $\sigma_{y^{\prime}}$ es la tensión aplicada sobre la dirección $\mathrm{y}^{\prime}\left(\mathrm{N} / \mathrm{mm}^{2}\right), \varepsilon_{x^{\prime}}$ es la deformación obtenida por la aplicación de la fuerza aplicada en la dirección $x^{\prime} y \varepsilon_{y^{\prime}}$ es la deformación obtenida por la aplicación de la fuerza aplicada en la dirección $y^{\prime}$. where $G$ is the shear modulus; $\sigma_{y^{\prime}}$ is the stress applied in the $y^{\prime}$ direction $\left(\mathrm{N} / \mathrm{mm}^{2}\right), \varepsilon_{X^{\prime}}$ is the deformation under the load applied in the $x^{\prime}$ direction and $\varepsilon_{y^{\prime}}$ is the deformation under the load applied in the $y^{\prime}$ direction.

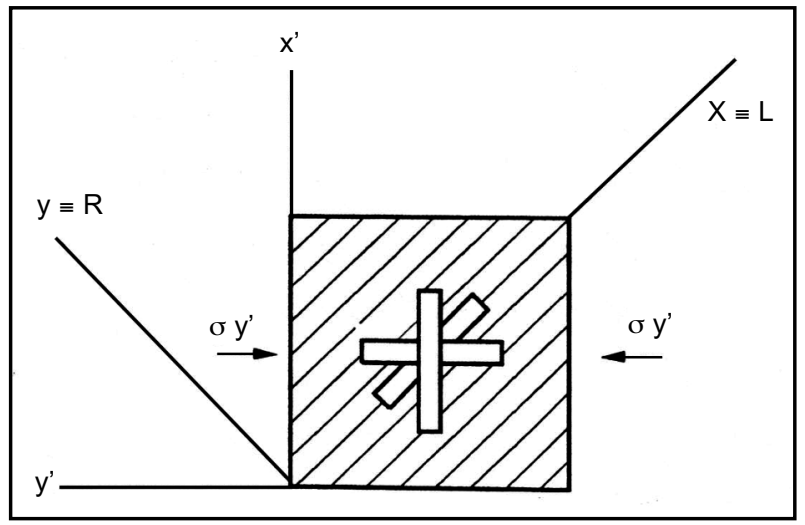

Figura 3. Esquema de ensayo de compresión en probetas con fibra orientada $45^{\circ}(20)$.

Figure 3. Diagram of compression tests on specimens with the grain at $45^{\circ}$ (20).

\subsection{Simulación numérica mediante MEF}

En el programa de elementos finitos ANSYS se modelizó la geometría una viga de sección 45 x $145 \mathrm{~mm}$ y longitud $3 \mathrm{~m}$ a partir de la generación de áreas rectángulo estratégicas en función de los puntos clave que definen el ensayo a flexión de cuatro puntos según la Norma UNEEN 408. Con el fin de evitar los efectos locales de las coacciones en la viga, se generaron placas de acero en los apoyos que disipasen la concentración de tensiones.

Según un análisis 2D en tensión plana con espesor igual a la base de la sección, se realizó el modelo con elementos finitos Plane42 de cuatro nodos de la biblioteca de elementos de ANSYS, buscando una malla lo más uniforme posible. Una vez generada la geometría y mallado de la viga, e introducidos los parámetros del material mediante programación APDL, se procedió a la programación de las propiedades del material para cada estado de tensión de viga.

\subsection{Modelización de la viga libre de defectos en tramo de comportamiento elástico}

Para la modelización de la viga libre de defectos en el tramo de comportamiento elástico de la madera, se asignaron los valores de módulo de elasticidad a tracción y a

\subsection{FEM numerical simulation}

The ANSYS finite element modelling package was used to model the geometry of a beam with a cross-section of $45 \times 145 \mathrm{~mm}$ and a length of $3 \mathrm{~m}$ by creating strategic rectangular areas according to the key points that define the four point bending test, according to UNE-EN 408 Standard (3). In order to avoid the local effects of constraints on the beam, steel plates were generated at the supports to minimize stress concentrations.

A $2 D$ plane stress analysis was assumed, considering that thickness equalled the base of the section. The model was developed with the four-node Plane42 finite element from Ansys element library, generating as uniform a mesh as possible. After the beam geometry and meshing were generated and the parameters of the material were fed into the model by using the APDL programming language, the properties of the material for each stress state of the beam were programmed.

\subsection{Modelling of the wood beam within the elastic range}

To model the defect free beam within the elastic range, the values of the tensile and compressive moduli of elasticity in the elastic region of the stress-strain curve 
compresión en la zona elástica de la curva tensión-deformación de la madera de Pinus sylvestris L. y se fue incrementando la carga hasta alcanzar, en la sección central, el límite elástico a compresión (Figura 4). Se denomina MP1 a las propiedades de la madera a tracción para una viga sometida a flexión; MP2 corresponde a las propiedades del acero de las placas de apoyo de la viga y MP3 es la madera a compresión en tramo elástico. for Scots pine timber were assigned, and the load was gradually increased until the compressive yield stress was reached at the central section of the beam (Figure 4). In Figure 4, MP1 corresponds to the tensile properties of Scots pine timber for a beam in bending; MP2 corresponds to the properties of the steel plates at the beam supports, and MP3 is wood under compression in the elastic phase.

NICIO / START

Asignación inicial de las propiedades del material a tracción en tramo elástico /

Initial allocation of the properties of the material in tension in the elastic phase: MP1

Aplicación de una carga puntual pequeña sobre la viga /

Application of a small point load to the beam: (FO)

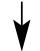

Análisis del estado tensional de los elementos: captura de los elementos comprimidos / Analysis of the stress state of the elements: the elements in compression are captured (MP1)

Cambio de las propiedades del material de estos elementos a las propiedades del material en compresión paralela en tramo elástico / The properties of the material of these elements change to the properties of the material in parallel compression in elastic phase (MP3)

\section{$y$}

Un elemento alcanza el valor del límite elástico a compresión / An element reaches the value of yield stress in compression:

$$
\begin{gathered}
\sigma_{\mathrm{c}, \mathrm{e}}=-39 \mathrm{~N} / \mathrm{mm}^{2} \\
\downarrow \quad \text { sí / YES }
\end{gathered}
$$

Comportamiento elastoplástico del material: cambio de las propiedades del material a las correspondientes a la tensión alcanzada / Elastic-plastic behaviour of the material: the properties of the material change to the properties that match the stress reached

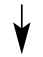

Se alcanza el límite de rotura a tracción paralela a la fibra / The tensile stress in tension parallel to the grain is reached:

$$
\begin{gathered}
\sigma_{\mathrm{t}, \mathrm{r}}=89 \mathrm{~N} / \mathrm{mm}^{2} \\
\downarrow \text { sí / YES } \\
\mathrm{FIN} / \mathrm{END}
\end{gathered}
$$

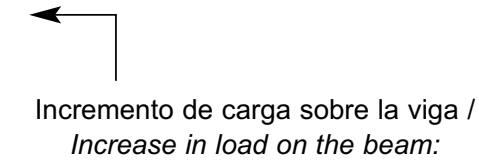
$F n+100$
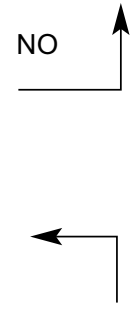

Incremento de carga sobre la viga / Increase in load on the beam: Fn+100

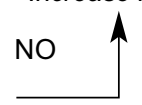

Figura 4. Esquema de la programación del modelo en el software ANSYS.

Figure 4. Diagram of the programming of the model in the ANSYS package.

Se inicia el análisis con una asignación de propiedades de la madera MP1 a todos los elementos. Se aplica sobre la viga una carga inicial muy pequeña y se almacenan todos los valores de tensión paralela a la fibra, comprobándose que los elementos con signo negativo están comprimidos $\left(\sigma_{\mathrm{c}, 0}\right)$ y los de signo positivo traccionados $\left(\sigma_{t, 0}\right)$. Se seleccionan los elementos comprimidos y se cambian las propiedades del material a su nuevo estado: cambio de tracción (MP1) a compresión (MP3). Este proceso se repite con cargas incrementales hasta que un elemento alcanza el valor del límite elástico a compresión para la madera de Pinus sylvestris $\mathrm{L}$. $\left(\mathrm{f}_{\mathrm{c}, 0, \mathrm{y}}\right)$ conocido a partir de los ensayos experimentales realizados sobre las probetas de esta especie.
At the beginning of the analysis all elements were designated MP1. a small initial load was applied to the beam and the values of stress parallel to the grain were recorded. We verified that the elements with negative values were under compression $\left(\sigma_{c, 0}\right)$ and the elements with positive values were in tension $\left(\sigma_{t, 0}\right)$. The elements in compression were chosen and the property type for these elements was changed to the new state, i.e., from MP1 (compression) to MP3 (tension). The process was repeated with incremental loads until one of the elements reached the compressive yield stress value for Scots pine timber $\left(f_{c, 0, y}\right)$, determined from the experimental tests performed on Scots pine specimens. 
Se introducen los valores de módulo de elasticidad perpendicular a la fibra, ecuación [7], y un coeficiente de Poisson $(\mu=0,4)$ y se continúa aumentando la carga iterativamente y realizando esta asignación de material a cada uno de los elementos que componen el mallado de la viga, generando un bucle de modo que se diferencien los elementos comprimidos y los traccionados para un incremento continuo de carga.
The values of the modulus of elasticity perpendicular to the grain, equation [7], and a Poisson's ratio ( $\mu=0.4)$ were incorporated into the model, the load was iteratively increased, and the material was assigned to every element in the beam mesh, such that a loop was generated. The loop allowed us to differentiate the elements in compression from the elements in tension for continuous load increases.

$$
E_{90}=E_{m} / 30
$$

donde $\mathrm{E}_{90}$ es el módulo de elasticidad perpendicular a la fibra y $E_{m}$ es el módulo de elasticidad aparente $\left(N / \mathrm{mm}^{2}\right)$ definido según la ecuación [1].

\subsection{Modelización de la viga libre de defectos en tramo de comportamiento elastoplástico}

Una vez alcanzado el límite elástico a compresión, la viga no rompe, sino que sigue admitiendo carga, de modo que los elementos comprimidos pasan a tener un comportamiento elastoplástico, alcanzando posteriormente la fluencia, hasta que se produce la rotura de la viga al alcanzar la tensión de rotura a tracción $\left(f_{t, 0, u}\right)$.

Para definir el comportamiento elastoplástico del material, el tramo curvo de compresión no lineal se discretiza en siete tramos lineales, donde los módulos de elasticidad van dando las diferentes pendientes de las rectas (poligonal) para sus correspondientes tensiones.

Una vez realizado el modelo que simula el ensayo de cuatro puntos de la viga sometida a flexión, se crea uno nuevo que simula varias vigas de sección 20 × $20 \mathrm{~mm}$ y luces de $122 \mathrm{~mm}, 238 \mathrm{~mm}, 318 \mathrm{~mm}$ y $520 \mathrm{~mm}$, que soportan una carga puntual en el centro de la viga, con el fin de conocer la influencia que la relación $E_{t, 0} / E_{c, 0}$ tiene en la deformación y en las tensiones.

\section{RESULTADOS Y DISCUSIÓN}

\subsection{Análisis experimental}

A partir de los ensayos sobre las probetas de madera libre de defectos, se obtienen los valores que definen la curva tensión-deformación de la madera de Pinus sylvestris $L$. de procedencia española. Para un total de 34 probetas ensayadas, el valor medio de módulo de elasticidad a compresión en fase elástica es de $\mathrm{E}_{\mathrm{c}, 0}=$ $8.096 \mathrm{~N} / \mathrm{mm}^{2}$ (Tabla 1), y el límite elástico a compresión, $\mathrm{f}_{\mathrm{c}, 0, \mathrm{y}}=-39 \mathrm{~N} / \mathrm{mm}^{2}$.
Where $E_{90}$ is the modulus of elasticity perpendicular to the grain and $E_{m}$ is the apparent modulus of elasticity $\left(\mathrm{N} / \mathrm{mm}^{2}\right)$, as given by equation [1].

\subsection{Modelling of the wood beam within the elastic-plastic range}

After having reached the compressive yield stress value, the beam did not fracture, which allowed for additional loads, such that the behaviour of the elements in compression became elastic-plastic. After that, the beam reached the yield point, and fracture occurred when the tensile yield limit value was reached $\left(s_{t, r}\right)$.

To define the elastic-plastic behaviour of the material, the curved region that represented non-linear compression was discretized into seven linear segments in which the moduli of elasticity gave the different slopes of the lines (polygonal) for the corresponding stresses.

Once the four point bending test model was created, a new model for a centred point load was designed. This model was used to simulate beams with a cross section of $20 \times 20 \mathrm{~mm}$ of several lengths: $122 \mathrm{~mm}, 238 \mathrm{~mm}, 318$ $\mathrm{mm}$ and $520 \mathrm{~mm}$, in order to determine the influence that the relation $E_{t, 0} / E_{c, 0}$ has on deformation and stresses.

\section{RESULTS AND DISCUSSION}

\subsection{Experimental test}

The values that define the strain-stress curve of Scots pine timber of Spanish provenance are obtained from the tests performed on wood specimens free from defects. For 34 test pieces, the mean value of the compressive modulus of elasticity in the elastic phase is $E_{c, 0}=8096$ $\mathrm{N} / \mathrm{mm}^{2}$ (Table 1), and the compressive yield stress is $f_{c, 0, y}=-39 \mathrm{~N} / \mathrm{mm}^{2}$. 
Tabla 1 / Table 1

Valores estadísticos del módulo de elasticidad en compresión paralela a la fibra en fase elástica. Statistical values of the modulus of elasticity in compression parallel to the grain in the elastic phase.

\begin{tabular}{|c|c|c|c|}
\hline \multicolumn{4}{|c|}{$\begin{array}{c}\text { Valores estadísticos del módulo de elasticidad en compresión en fase elástica }\left(\mathrm{N} / \mathrm{mm}^{2}\right) \text { / Statistical values of the compressive modulus } \\
\text { of elasticity in the elastic phase }\left(\mathrm{N} / \mathrm{mm}^{2}\right)\end{array}$} \\
\hline$n$ & Media / Mean & Menor / Lowest & Mayor / Highest \\
\hline 34 & 8096 & 6878 & 9688 \\
\hline
\end{tabular}

Se obtuvieron, además, los distintos módulos de elasticidad correspondientes a las diferentes tensiones que describen la curva de elastoplasticidad de comportamiento de la madera (Tabla 2) y el valor de tensión de rotura a compresión paralela a la fibra, $\mathrm{f}_{\mathrm{c}, 0, \mathrm{u}}=-57 \mathrm{~N} / \mathrm{mm}^{2}$.
In addition, we obtained the moduli of elasticity for the different stresses that define the elastic-plastic curve for Scots pine timber (Table 2), and the value of the ultimate strength in compression parallel to the grain, $f_{c, 0, u}=-57 \mathrm{~N} / \mathrm{mm}^{2}$.

Tabla 2 / Table 2

Valores de módulos de elasticidad en tramo elastoplástico.

Values of the modulus of elasticity in the elastic-plastic phase.

\begin{tabular}{|c|c|}
\hline Compresión en fase elastoplástica / Stress in elastoplastic phase (N/mm $\left.{ }^{2}\right)$ & Módulo de elasticidad / Modulus of elasticity (N/mm ${ }^{2}$ ) \\
\hline$\sigma<-57$ & 100 \\
\hline$-57 \leq \sigma<-55$ & 500 \\
\hline$-55 \leq \sigma<-52$ & 1100 \\
\hline$-52 \leq \sigma<-50$ & 2000 \\
\hline$-50 \leq \sigma<-45$ & 2700 \\
\hline$-45 \leq \sigma<-41$ & 3300 \\
\hline$-41 \leq \sigma<-39$ & 4200 \\
\hline$-39 \leq \sigma<0$ & 8100 \\
\hline$\sigma \geq 0$ & 9720 \\
\hline
\end{tabular}

Para un total de 82 probetas ensayadas, el valor medio de tensión de rotura a tracción es de $\mathrm{f}_{\mathrm{t}, 0, \mathrm{u}}=89 \mathrm{~N} / \mathrm{mm}^{2}$ (Tabla 3).
For a total of 82 specimens, the mean value of the ultimate tensile strength is $f_{t, 0, u}=89 \mathrm{~N} / \mathrm{mm}^{2}$ (Table 3).

Tabla 3 / Table 3

Valores de tensión de rotura a tracción paralela a la fibra, $\mathrm{f}_{\mathrm{t}, 0, \mathrm{u}}$. Values of ultimate strength in tension parallel to the grain.

\begin{tabular}{|c|c|c|c|}
\hline \multicolumn{3}{|c|}{ Valores estadísticos del ensayo de rotura a tracción paralela a la fibra / Statistical values of ultimate strength in axial tension (N/mm²) } \\
\hline $\mathbf{n}$ & Media / Mean & Menor / Lowest & Mayor / Highest \\
\hline 82 & 89.05 & 38.3 & 143.934 \\
\hline
\end{tabular}

Para un total de 32 ensayos a compresión oblicua, el valor medio de módulo de elasticidad transversal fue de $\mathrm{G}=604,3 \mathrm{~N} / \mathrm{mm}^{2}$ (Tabla 4).
For a total of 32 oblique compression tests, the mean value of the shear modulus is $G=604.3 \mathrm{~N} / \mathrm{mm}^{2}$, (Table 4).

Tabla 4 / Table 4

Valores estadísticos del ensayo de módulo de elasticidad transversal.

Values of the shear modulus of elasticity, $G$.

\begin{tabular}{|c|c|c|c|}
\hline \multicolumn{3}{|c|}{ Valores estadísticos del ensayo de módulo de elasticidad transversal / Statistical values of the shear modulus of elasticity (N/mm²) } \\
\hline $\mathbf{n}$ & Media / Mean & Menor / Lowest & Mayor / Highest \\
\hline 32 & 604.3 & 476.0 & 751.0 \\
\hline
\end{tabular}

El diagrama tensión-deformación para la especie Pinus sylvestris $\mathrm{L}$. de procedencia española adopta los valores representados en la Figura 1.
The stress-strain curve for Scots pine of Spanish provenance takes the values plotted in Figure 1. 


\subsection{Simulación numérica}

A partir de la simulación numérica de la viga, que representa el ensayo a flexión de cuatro puntos según la Norma UNE-EN 408 (3), se obtiene la distribución de los elementos que componen la viga (Figura $5 \mathrm{a}$ ). El material MP1 se corresponde con los valores de módulo de elasticidad a tracción paralela a la fibra $\left(E_{t, 0}=9.720 \mathrm{~N} / \mathrm{mm}^{2}\right.$, para una estimación de $E_{t, 0} / E_{c, 0}=1,2$ ), el material MP2 se corresponde con las propiedades del acero de los apoyos y el material MP3 representa los elementos que adoptan el módulo de elasticidad a compresión paralela a la fibra en tramo elástico $\left(\mathrm{E}_{\mathrm{c}, 0}=8.100 \mathrm{~N} / \mathrm{mm}^{2}\right)$.

Gracias a la modelización generada mediante el método de los elementos finitos, se obtiene la distribución de tensiones en el tramo elástico a lo largo del canto, para una sección central de la viga, situada entre los dos puntos de aplicación de la carga, donde se aprecia el comportamiento lineal del material y un pequeño descenso de la fibra neutra con respecto al eje longitudinal de la viga (Figura 6a). En la zona de la viga sometida a compresión, las tensiones alcanzan su valor máximo en -39 N/mm² (límite elástico a compresión, $\mathrm{f}_{\mathrm{c}, 0, \mathrm{y}}$ ), representado con el color azul oscuro, mientras que en la zona de la viga sometida a tracción, el valor máximo de tensión a tracción es de $46,7 \mathrm{~N} / \mathrm{mm}^{2}$, todavía muy por debajo del límite de rotura a tracción paralela a la fibra $\left(\mathrm{f}_{\mathrm{t}, 0, \mathrm{u}}=89 \mathrm{~N} / \mathrm{mm}^{2}\right)$, que se alcanza para una carga máxima aplicada de $13,8 \mathrm{kN}$.

El modelo numérico generado permite visualizar el comportamiento tensional de cada uno de los elementos de mallado que componen la viga durante todo el proceso de carga, hasta el momento de la rotura (Figura $5 b$ ). Se muestra la distribución de los elementos sometidos a compresión y a tracción en el momento en que se alcanza la rotura por tracción paralela a la fibra, además de los elementos comprimidos en el tramo elastoplástico. En la zona superior de la viga se concentran los elementos con comportamiento elastoplástico. El modelo simula el verdadero ensayo a flexión de cuatro puntos, de modo que es posible obtener la flecha alcanzada por la viga durante todo el proceso de aplicación de la carga y la distribución de tensiones en la viga.

Se obtiene también la distribución de tensiones a lo largo del canto de la viga en el momento de rotura de la viga por tracción paralela a la fibra (Figura 6b). La gráfica recoge el comportamiento lineal de la madera a tracción y el tramo elastoplástico en la zona comprimida, con valores entre 39 y $57 \mathrm{~N} / \mathrm{mm}^{2}$, representado por el tramo curvo de la gráfica. El valor de $89 \mathrm{~N} / \mathrm{mm}^{2}$ alcanzado en la zona traccionada es el indicador de la rotura de la viga de Pinus sylvestris L., para una carga máxima aplicada de $21,1 \mathrm{kN}$.

\subsection{Numerical simulation}

The numerical simulation of the beam, which represents a four point bending test according to UNE EN 408 (3) standard, generates the distribution of the elements that compose the beam (Figure 5a). Material MP1 corresponds to the values of the modulus of elasticity in tension parallel to the grain $\left(E_{t, 0}=9720 \mathrm{~N} / \mathrm{mm}^{2}\right.$, for a ratio of $\left.E_{t, 0} / E_{c, 0}=1.2\right)$, material MP2 corresponds to the properties of steel at the beam supports, and material MP3 represents the elements that assume the modulus of elasticity in compression parallel to the grain within the elastic range $\left(E_{c, 0}=8100 \mathrm{~N} / \mathrm{mm}^{2}\right)$.

The generated finite element model simulates stress distribution along the beam depth for the central section of the beam, between the two points of load application, where the material behaves linearly and the neutral axis slightly shifts downwards with respect to the longitudinal axis of the beam (Figure 6a). In the portion of beam that is subjected to compression, stresses reach their peak value at $-39 \mathrm{~N} / \mathrm{mm}^{2}$ (compressive yield stress, $f_{c, 0, y}$ ), plotted in deep blue, whereas in the portion of beam that is subjected to tension, the maximum stress value in tension is $46.7 \mathrm{~N} / \mathrm{mm}^{2}$, far below the yield limit in tension parallel to the grain $\left(f_{t, 0, u}=89 \mathrm{~N} / \mathrm{mm}^{2}\right)$, which is reached for a maximum applied load of $13.8 \mathrm{kN}$.

The generated numerical model has allowed us to visualize the stress behaviour of every mesh element that composes the beam during the whole load application process until failure (Figure $5 b$ ). The model shows the distribution of the elements in compression and tension at fracture in tension parallel to the grain, and the elements in compression in the elastic-plastic range. Elastic-plastic elements concentrate in the upper section of the beam. Because the model simulates the actual four point bending test, we can obtain the deflection of the beam during the whole load application process and the stress distribution along the beam.

In addition, we have obtained the stress distribution along the beam depth at fracture in tension parallel to the grain (Figure 6b). The figure shows the linear behaviour of clear wood in tension and the elasticplastic range in the area under compression, with values in the range 39 and $57 \mathrm{~N} / \mathrm{mm}^{2}$, represented by the curved region in the diagram. The value of $89 \mathrm{~N} / \mathrm{mm}^{2}$ reached in the section subjected to tension suggests fracture of the Scots pine beam at a maximum applied load of $21.1 \mathrm{kN}$. 


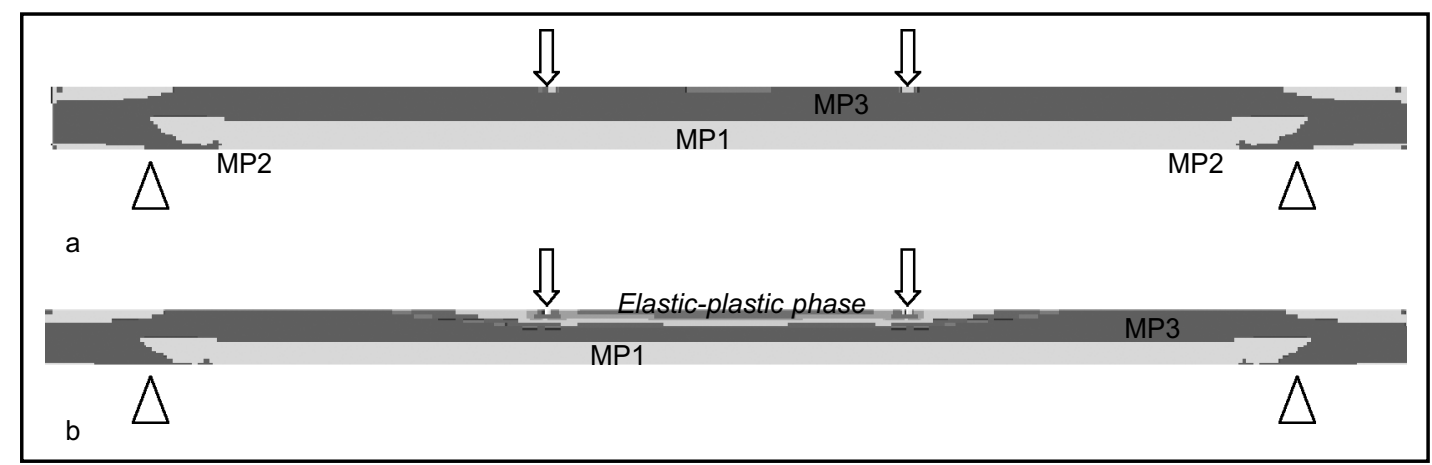

Figura 5. Atribución de materiales asignados a los distintos módulos de elasticidad de la madera en fase elástica (a) y en fase elastoplástica (b).

Figure 5. Allocation of materials assigned to the different moduli of elasticity of timber in the elastic phase (a) and in the elastic-plastic phase (b).

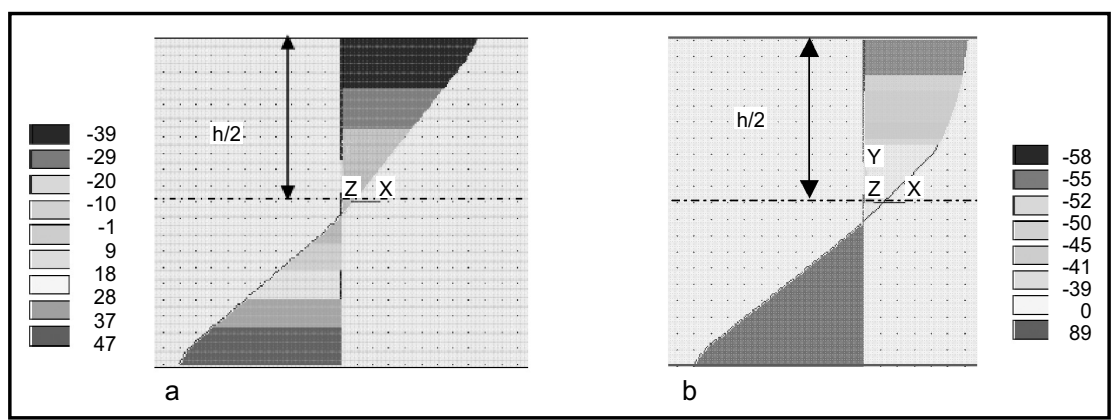

Figura 6. Distribución de tensiones a lo largo de la sección central de la viga en el tramo elástico de comportamiento (a) y en el tramo elastoplástico de comportamiento (b).

Figure 6. Stress distribution along the central section of the beam in the elastic phase (a) and in the elastic-plastic phase (b).

\subsection{Influencia de la relación entre los módulos de tracción y compresión en la deformación y en las tensiones}

El módulo de elasticidad longitudinal paralelo a la fibra es el parámetro que más influye en la deformación, sirviendo como referencia para relacionar con los demás módulos de elasticidad. Sin embargo, al presentar la madera un módulo de elasticidad longitudinal diferente a tracción y a compresión, es importante determinar si la relación entre dichos módulos de elasticidad puede ser significativa.

En base a los valores de módulo de elasticidad a compresión paralela a la fibra obtenidos en los ensayos experimentales se toma el módulo de elasticidad a tracción paralela a la fibra en función de una serie de relaciones entre ambos valores. Las relaciones consideradas son las siguientes: $\mathrm{E}_{\mathrm{t}, 0} / \mathrm{E}_{\mathrm{c}, 0}=1,0 ; \mathrm{E}_{\mathrm{t}, 0} / \mathrm{E}_{\mathrm{c}, 0}=1,2 ; \mathrm{E}_{\mathrm{t}, 0} / \mathrm{E}_{\mathrm{c}, 0}=1,3$; $\mathrm{E}_{\mathrm{t}, 0} / \mathrm{E}_{\mathrm{c}, 0}=1,4$, de modo que los módulos de elasticidad a tracción paralela a la fibra considerados en la simulación numérica son $\mathrm{E}_{\mathrm{t}, 0}=8.100 \mathrm{~N} / \mathrm{mm}^{2}, \mathrm{E}_{\mathrm{t}, 0}=9.720$ $\mathrm{N} / \mathrm{mm}^{2}, E_{t, 0}=10.530 \mathrm{~N} / \mathrm{mm}^{2}$ y $E_{t, 0}=11.340 \mathrm{~N} / \mathrm{mm}^{2}$ respectivamente. Los valores de deformación y de tensión se obtienen mediante simulación numérica para cada una de las relaciones consideradas, excepto en el caso de la relación $E_{t, 0} / E_{c, 0}=1,0$, que es abordable

\subsection{Effects of the relation between modulus of tension and compression on deformation and stresses}

The longitudinal modulus of elasticity parallel to the grain is the factor that most affects deformation and is used as a reference for the relations with other moduli of elasticity. Yet, timber has differering longitudinal moduli of elasticity in tension and in compression. Consequently, it is important to determine whether the relation between such moduli of elasticity is meaningful.

Because data of the modulus of elasticity in tension parallel to the grain could not be derived from experimental tests, we considered a number of $E_{t, 0} / E_{c, 0}$ ratios to determine the modulus of elasticity in tension parallel to the grain. The following ratios were used: $E_{t, 0} / E_{c, 0}=1.0 ; E_{t, 0} / E_{c, 0}=1.2 ; E_{t, 0} / E_{c, 0}=1.3 ; E_{t, 0} / E_{c, 0}=1.4$, such that the moduli of elasticity in tension parallel to the grain considered in the numerical simulation were $E_{t, 0}=8100 \mathrm{~N} / \mathrm{mm}^{2}, E_{t, 0}=9720 \mathrm{~N} / \mathrm{mm}^{2}, E_{t, 0}=10530$ $\mathrm{N} / \mathrm{mm}^{2}$ and $E_{t, 0}=11340 \mathrm{~N} / \mathrm{mm}^{2}$ respectively. Stress and deformation values were obtained by numerical simulation for each considered relationship of modulus of elasticity, except for $E_{t, 0} / E_{c, 0}=1,0$, which was calculated according to the strength of materials taking into 
mediante la teoría de resistencia de materiales. Para abordar este cálculo, se ha tenido en cuenta la influencia del esfuerzo cortante con una relación $\mathrm{G}=\mathrm{E} / 16$.

A continuación, los valores anteriores de la relación $\mathrm{E}_{\mathrm{t}, 0} / \mathrm{E}_{\mathrm{c}, 0}$ se aplican a un caso de una viga de sección cuadrada de lado igual a $20 \mathrm{~mm}$ con una carga puntual de $1.333 \mathrm{~N}$ situada en el centro del vano y con esbelteces (luz/canto) crecientes desde 6,1 hasta 15,9, pudiendo observar la influencia en la rigidez aparente de la viga.

La Figura 7 muestra la relación entre la rigidez (deformación por unidad de carga) para distintas esbelteces. Se aprecia que, a medida que aumenta la esbeltez, aumenta también la rigidez. Esto en parte se debe a que un aumento de $E_{t, 0}$, para un valor de $E_{c, 0}$ constante, implica un aumento del módulo de elasticidad medio, $\mathrm{E}_{\mathrm{m}}$, según la ecuación [1].

La Tabla 5 muestra los valores de rigidez para cada esbeltez de viga y cada relación entre el módulo de elasticidad a tracción y a compresión. Las columnas de la derecha representan las diferencias de deformación, en $\mathrm{mm} / \mathrm{kN}$ y en $\%$, de cada una de las relaciones $E_{t, 0} / E_{c, 0}$ consideradas con respecto a la relación $\mathrm{E}_{\mathrm{t}, 0} / \mathrm{E}_{\mathrm{c}, 0}=1$. La diferencia varía entre un $7,7 \%$ para el caso de la viga con menor esbeltez y para una relación $\mathrm{E}_{\mathrm{t}, 0} / \mathrm{E}_{\mathrm{c}, 0}=1,2 \mathrm{y}$ $16,7 \%$ para la viga con mayor esbeltez y mayor relación entre módulo de elasticidad a tracción y a compresión $\left(E_{t, 0} / E_{c, 0}=1,4\right)$.

La influencia en la rigidez para una relación $\mathrm{E}_{\mathrm{t}, 0} / \mathrm{E}_{\mathrm{c}, 0}=1,2$ varía entre un $7,7 \%$ y un $10,7 \%$; para una relación $E_{t, 0} / E_{c, 0}=1,3$ varía entre un $9,6 \%$ y un $14,0 \%$ y para una relación de $E_{t, 0} / E_{c, 0}=1,4$, las variaciones se encuentran entre 11,5 y $16,7 \%$. Se aprecia que para las esbelteces mayores, la influencia de las distintas relaciones $E_{t, 0} / E_{c, 0}$ con respecto a la relación igual a 1 son similares. account the influence of shear stress using the value $G=E / 16$.

Next, the previous values of the relationship $E_{t, 0} / E_{c, 0}$, were applied to a beam with a cross section of $20 x$ $20 \mathrm{~mm}$ and slenderness increasing from 6.1 to 15.9. A punctual centred load of $1333 \mathrm{~N}$ was placed in the centre the span and the influence of these parameters on the stiffness of the beam were observed.

Figure 7 shows the relationship between stiffness (unit load deflection) for different slenderness. We can see that, as the slenderness increases, also increases the stiffness. This is in part due to an increase of $E_{t, 0}$ for a constant $E_{c, 0}$ value implies an increase in modulus of elasticity $E_{m}$ according to equation [1].

Table 5 shows the values of stiffness for each slenderness of beam and each relationship between modulus of elasticity in tension and compression. The right columns represent the differences of deformation, in $\mathrm{mm} / \mathrm{kN}$ and $\%$, of the relationships $E_{t, 0} / E_{c, 0}$ considered with respect to the relation $E_{t, 0} / E_{c, 0}=1$. The difference varies between $7,7 \%$ in the case of the less slenderness beam with a ratio $E_{t, 0} / E_{c, 0}=1.2$ and $16.7 \%$ for the beam with greater slenderness and ratio $E_{t, 0} / E_{c, 0}=1.4$.

Influence on stiffness for a relationship $E_{t, 0} / E_{c, 0}=1.2$ varies between $7,7 \%$ and $10,7 \%$; for a relationship $E_{t, 0} / E_{c, 0}=1.3$ varies between $9.6 \%$ and $14.0 \%$ and for a relationship $E_{t, 0} / E_{c, 0}=1.3$, between $11.5 \%$ and $16.7 \%$. When the slenderness are higher, the influence of the different relationships $E_{t, 0} / E_{c, 0}$ with respect to the same relationship equal to 1 , are similar.

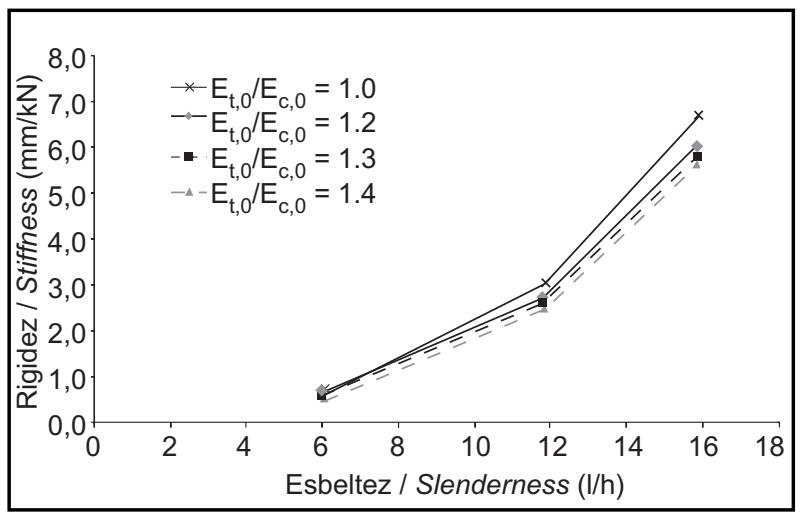

Figura 7. Influencia de la relación $\mathrm{E}_{\mathrm{t}, 0} / \mathrm{E}_{\mathrm{c}, 0}$ en la rigidez para una viga biapoyada de diferentes esbelteces con una carga puntual centrada.

Figure 7. Effects of the $E_{t, 0} / E_{c, 0}$ ratio on stiffness for a beam with two supports and a centered point load. 
Tabla 5 / Table 5

Rigidez obtenida mediante simulación numérica en función de la esbeltez de la viga y de la relación $E_{t, 0} / E_{c, 0}$. Stiffness obtained according to the numerical simulation as a function of slenderness and $E_{t, 0} / E_{c, 0}$.

\begin{tabular}{|c|c|c|c|c|}
\hline $\begin{array}{c}\text { Esbeltez I } \\
\text { Slenderness, I/h }\end{array}$ & $\begin{array}{l}\text { Relación entre módulos de elasticidad a tracción } \\
\text { y compresión / Relation between modulus of elasticity } \\
\text { in tension and compression, } \mathrm{E}_{\mathrm{t}, 0} / \mathrm{E}_{\mathrm{c}, 0}\end{array}$ & $\begin{array}{c}\text { Rigidez I } \\
\text { Stiffness }(\mathrm{mm} / \mathrm{kN})\end{array}$ & $\begin{array}{l}\text { Diferencia / } \\
\text { Difference } \\
(\mathrm{mm} / \mathrm{kN})\end{array}$ & $\begin{array}{c}\text { Diferencia / } \\
\text { Difference (\%) }\end{array}$ \\
\hline \multirow{4}{*}{6.1} & 1.0 & 0.53 & 0.00 & 0.0 \\
\hline & 1.2 & 0.49 & -0.04 & -7.7 \\
\hline & 1.3 & 0.48 & -0.05 & -9.6 \\
\hline & 1.4 & 0.47 & -0.06 & -11.5 \\
\hline \multirow{4}{*}{11.9} & 1.0 & 2.95 & 0.00 & 0.0 \\
\hline & 1.2 & 2.63 & -0.32 & -10.9 \\
\hline & 1.3 & 2.55 & -0.40 & -13.7 \\
\hline & 1.4 & 2.47 & -0.48 & -16.4 \\
\hline \multirow{4}{*}{15.9} & 1.0 & 6.67 & 0.00 & 0.0 \\
\hline & 1.2 & 5.96 & -0.71 & -10.7 \\
\hline & 1.3 & 5.74 & -0.93 & -14.0 \\
\hline & 1.4 & 5.56 & -1.11 & -16.7 \\
\hline
\end{tabular}

Dicha relación también tiene influencia en las tensiones máximas en tramo elástico. Las relaciones entre la tensión de tracción y compresión tienden, a medida que aumenta la luz de la viga asintóticamente, a la expresión de la ecuación [8].
However, the relation between both moduli of elasticity affects maximum stress. With the asymptotic growth of the span of the beam, the relations between stress in tension and stress in compression tend to the expression in equation [8].

$$
\sigma_{t, 0} / \sigma_{c, 0}=\sqrt{\left(E_{t, 0} / E_{c, 0}\right.}
$$

Para pequeñas luces no se cumple exactamente esta relación debido a que la influencia de las tensiones originadas por el esfuerzo cortante son relativamente importantes frente a las tensiones originadas por el momento flector. A medida que la luz aumenta, la influencia se va haciendo menor (Figura 8).
For short spans, this ratio is not exactly satisfied because of the effects of the stress caused by the shear stress, which are relatively important as compared to the stress caused by the bending moment. Such effects decrease gradually with the increase in span (Figure 8).

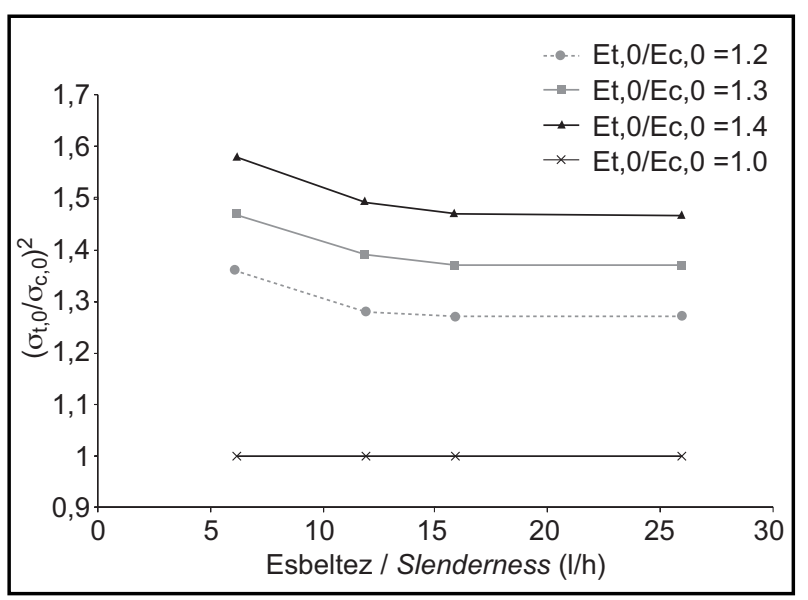

Figura 8. Influencia de la relación $\mathrm{E}_{\mathrm{t}, 0} / \mathrm{E}_{\mathrm{c}, 0}$ en las tensiones para una viga biapoyada de diferentes esbelteces con una carga puntual centrada.

Figure 8. Effects of the $E_{t, 0} / E_{c, 0}$ ratio on stress for a beam with two supports and a centered point load. 


\section{CONCLUSIONES}

Mediante el presente trabajo se propone el análisis del comportamiento elastoplástico de la madera mediante el empleo de la simulación numérica a partir de elementos finitos considerando propiedades elásticas variables e incrementos sucesivos de tensión.

A partir de ensayos experimentales se obtuvieron los valores correspondientes a la curva tensión-deformación para la especie Pinus sy/vestris L. de procedencia española, con valores de límite elástico a compresión $\left(\mathrm{f}_{\mathrm{c}, 0, \mathrm{y}}=-39 \mathrm{~N} / \mathrm{mm}^{2}\right)$, límite de rotura a compresión $\left(\mathrm{f}_{\mathrm{c}, 0, \mathrm{u}}=-57 \mathrm{~N} / \mathrm{mm}^{2}\right)$ y límite de rotura a tracción $\left(\mathrm{f}_{\mathrm{t}, 0, \mathrm{u}}=89 \mathrm{~N} / \mathrm{mm}^{2}\right)$.

El modelo creado mediante el método de los elementos finitos simula el ensayo de cuatro puntos definido en la Norma UNE-EN 408 (3) y permite predecir la rotura de una viga libre de defectos por tracción paralela a la fibra y el fallo por compresión paralela a la fibra, permitiendo la modelización de cualquier tipo de viga libre de defectos.

Asimismo, permite deducir el descenso de la fibra neutra que se produce en la viga debido a los diferentes valores de módulos de elasticidad paralelos a la fibra en tracción y en compresión.

La modelización de vigas biapoyadas con carga puntual centrada se utilizó para analizar la influencia que la relación $\mathrm{E}_{\mathrm{t}, 0} / \mathrm{E}_{\mathrm{c}, 0}$ tiene en la deformación y en las tensiones. Esta relación tiene una influencia que varía entre el $7,7 \%$ y el $16,7 \%$ sobre la deformación e influye de forma decreciente en las tensiones a medida que la luz de la viga aumenta. Se considera, por lo tanto, conveniente la necesidad de obtención del módulo de elasticidad a tracción según métodos experimentales.

\section{AGRADECIMIENTOS}

Ministerio de Ciencia e Innovación. Plan Nacional de I+D+i. Ref.: AGL2009-11331. Título del proyecto de investigación: "Propuesta metodológica de cálculo y ensayo de tipologías de uniones carpinteras recientemente implantadas en estructuras de madera e influencia de los nudos en la capacidad de carga" (2009-2012).

\section{CONCLUSIONS}

With this paper an analysis of elastoplastic behaviour of timber, using numerical simulation, is proposed. The finite element method was used considering elastic and elastoplastic properties, and also successive increments of stress in the beam.

Based on experimental tests, we obtained the values of the stress-strain curve for Scots pine wood of Spanish provenance, with values of compressive yield stress $f_{c, 0, y}=-39 \mathrm{~N} / \mathrm{mm}^{2}$, ultimate compressive strength $f_{c, 0, u}=-57 \mathrm{~N} / \mathrm{mm}^{2}$ and ultimate tensile strength $f_{t, 0, u}=89 \mathrm{~N} / \mathrm{mm}^{2}$ ).

The generated finite element model simulates the four point bending test defined in the UNE-EN 408 standard and allows for the prediction of fracture of a wood without defects beam in tension parallel to the grain and failure in compression parallel to the grain, which allows for the modelling of any type of clear wood beam.

In addition, the model captures the downward shift of the neutral axis of the beam caused by the differing values of the modulus of elasticity in tension parallel to the grain and the modulus of elasticity in compression parallel to the grain.

The model of simple supported beams with a centred point load was used to analyse the effect that the relation $E_{t, 0} / E_{c, 0}$ has on stiffness and stresses. This relationship has an influence that varies between $7.7 \%$ and $16.7 \%$ on stiffness and a decreasing influence on stresses as the length of beam increases. Therefore, it is recommended to obtain de modulus of elasticity in tension through experimental testing.

\section{ACKNOWLEDGEMENTS}

Ministerio de Ciencia e Innovación. Plan Nacional de I+D+i. Ref.: AGL2009-11331. Research Project titled: "Propuesta metodológica de cálculo y ensayo de tipologías de uniones carpinteras recientemente implantadas en estructuras de madera e influencia de los nudos en la capacidad de carga" (2009-2012).

\section{BIBLIOGRAFÍA / BIBLIOGRAPHY}

(1) Argüelles Álvarez, R.; Arriaga Martitegui, F.; Martínez Calleja, J. J.: "Estructuras de madera. Diseño y cálculo", AITIM, Madrid (2003).

(2) Hermoso Prieto, E.; Fernández-Golfín Seco, J. I.; Díez Barra, M. R.: "Mechanical characterization of timber according to European standards from Spanish provenances of Scots Pine", Invest. Agrar.: Sist. Recur. For, vol. 12, no 3 (2003), pp. 103-110.

(3) UNE-EN 408:2004: "Estructuras de madera. Madera aserrada y madera laminada encolada para uso estructural. Determinación de algunas propiedades físicas y mecánicas". 
(4) UNE-EN 384:2010. "Madera Estructural. Determinación de los valores característicos de las propiedades mecánicas y la densidad".

(5) UNE-EN 338:2010. "Madera Estructural. Clases resistentes".

(6) Fernández-Golfín, J. I.; Díez, M. R.; Hermoso, E.: "Relationships between grade determining properties of Spanish Scots and Laricio Pine structural timber", Mater. Construcc., vol. 53, nº 270 (2003), pp. 44-45.

(7) Gupta, R.; Heck L. R.; Miller T. H.: "Finite-element analysis of the stress distribution in a torsion test of full-size, structural lumber", J. Test Eval., vol. 30, no 4 (2002), pp. 291-302. http://dx.doi.org/10.1520/JTE12319]

(8) Dubois, F.; Chazal, C.; Petit, C.: "Viscoelastic crack growth process in wood timbers: an approach by the finite element method for mode I fracture", International journal of fracture, vol. 113, no 4 (2002), pp. 367-388. http://dx.doi.org/10.1023/A:1014203405764

(9) Landis, E. N.; Vasic, S.; Davids, W. G.; Parrod, P.: "Coupled experiments and simulations of microstructural damage in wood", Experimental Mechanics, vol. 42, no 4 (2003), pp. 389-394.

(10) Landis, E. N.; Fournier, C. R.; Davids, W. G.; Nagy, E.: "Morphological lattice models for the simulation of softwood failure and fracture", Holzforschung; vol. 61, no 4 (2007), pp. 360-366. http://dx.doi.org/10.1515/HF.2007.050

(11) Coreau, J. L.; Gustafsson, P.; Persson, K.: "Elastic layer model for application problems in timber engineering", Wood science and technology, vol. 40, no 4 (2006), pp. 275-290. http://dx.doi.org/10.1007/s00226-005-0033-x

(12) Ormarsson, S.; Petersson, H.; Erikson, J.: "Finite-element analysis of coupled nonlinear heat and moisture transfer in wood", Numerical heat transfer par A-Aplications, vol. 50, no 9 (2006), pp. 851-864.

(13) Daudeville, L.: "Fracture in spruce: experiment and numerical analysis by linear and non-linear fracture", Holz roh Werkstoff, vol. 57, no 6 (1999), pp. 425-432. http://dx.doi.org/10.1007/s001070050068

(14) Williams, J. M.; Friedley, K. J.; Cofer, W. F.; Falk, R. H.: "Failure modeling of sawn lumber with a fastener hole", Finite Element in Analysis and Design, vol. 36, no 1 (2000), pp. 83-98. http://dx.doi.org/10.1016/S0168-874X(00)00010-X

(15) Chassagne, P.; Bou-Said, E.; Jullien, J. F.; Galimard, P.: "Three dimensional creep model for wood under variable humidity-numerical analyses at different material scales", Mechanics of time-dependent material, vol. 9, no 4 (2005), pp. 203-223.

(16) Villar, J. R.; Guaita, M.; Vidal, P.; Arriaga, F.: "Analysis of the stress state at the cogging joint in timber structures", Biosystem engineering, vol. 96, no 1 (2007), pp. 79-90.

(17) Villar, J. R.; Guaita, M.; Vidal, P.; Argüelles Bustillo, R.: "Numerical simulation of framed joints in sawn-timber roof structures", Spanish journal of agricultural research, vol. 6, no 4 (2008), pp. 508-520.

(18) Köck, B.; Holzel S. M.: "The load-displacement behaviour of halved joints", Proceedings of World Conference Timber Engineering (2010).

(19) Jasieńko, J.; Nowak, T.; Czepiżak, D.: "Numerical analysis of CFRP-Reinforced wooden beams under bending", Proceedings of World Conference Timber Engineering (2010).

(20) UNE 56535:1977: "Características físico-mecánicas de la madera. Determinación de la resistencia a la compresión axial".

(21) Argüelles Bustillo, R.: "Predicción con simulación animada del comportamiento de piezas de madera", Tesis Doctoral, Universidad Politécnica de Madrid, Escuela Técnica Superior de Ingenieros de Montes (1994). 